\title{
A Deusa em Camelot: o papel da mulher na concepção e evolução dos heróis arturianos
}

Tese de Doutoramento em Literaturas Românicas apresentada à Faculdade de Ciências Sociais e Humanas da Universidade Nova de Lisboa, em Novembro de 2008. Orientação do Prof. Doutor Helder Godinho

\section{Ana Margarida Chora}

\section{(2) OpenEdition}

\section{Journals}

Edição electrónica

URL: http://journals.openedition.org/medievalista/479

DOI: 10.4000/medievalista.479

ISSN: 1646-740X

\section{Editora}

Instituto de Estudos Medievais - FCSH-UNL

\section{Refêrencia eletrónica}

Ana Margarida Chora, «A Deusa em Camelot: o papel da mulher na concepção e evolução dos heróis arturianos », Medievalista [Online], 8 | 2010, posto online no dia 01 dezembro 2010, consultado o 15 setembro 2020. URL : http://journals.openedition.org/medievalista/479

\section{(c) (†) 8)}


Titulo: Apresentação de Tese

A Deusa em Camelot: o papel da mulher na concepção e evolução dos heróis arturianos.

Tese de Doutoramento em Literaturas Românicas apresentada à Faculdade de Ciências Sociais e Humanas da Universidade Nova de Lisboa, em Novembro de 2008. Orientação do Prof. Doutor Helder Godinho.

Autor(es): Ana Margarida Chora

Enquadramento Institucional: CEIL - Faculdade de Ciências Sociais e

Humanas, Universidade Nova de Lisboa

Contacto: ana.chora@vizzavi.pt

Fonte: Medievalista [Em linha]. №8, (Julho 2010). Direc. José Mattoso. Lisboa: IEM.

Disponível em: http://www2.fcsh.unl.pt/iem/medievalista/

ISSN: 1646-740X 


\section{Apresentação de Tese}

\section{A Deusa em Camelot: o papel da mulher na concepção e evolução dos heróis arturianos.}

Tese de Doutoramento em Literaturas Românicas apresentada à Faculdade de Ciências Sociais e Humanas da Universidade Nova de Lisboa, em Novembro de 2008. Orientação do Prof. Doutor Helder Godinho.

\section{Ana Margarida Chora}

A presente tese pretende, sob uma perspectiva mitocrítica, analisar o papel das figuras femininas arturianas no percurso dos respectivos heróis. Personagens como a Dama do Lago, a fada Morgana, a rainha Guenièvre e outras, menos conhecidas, como a Dama de Malehault, a encantadeira Gamille ou mesmo a Dama de Avalon, desempenham um papel fundamental na evolução de heróis como Lancelot, Gauvain, Perceval, Hector, Lionel e muitos outros, cuja ligação à mulher está presente desde a sua concepção até à morte ou, melhor dizendo, desde o início do percurso heróico até à sua finalização.

Partindo da própria importância da evolução dos estudos arturianos, das suas preferências e do terreno que os estudos do feminino têm vindo a ganhar, considerámos a mitologia celta e o seu fundo mítico, bem como os esquemas heróicos arquetípicos de Jung e Otto Rank como base de análise.

Se bem que o corpus central (mais extenso, divulgado e até mediatizado) da Matéria da Bretanha seja a chamada Vulgata (que contém os textos franceses em prosa referentes a Lancelot e ao Graal, do início do séc. XIII), a problemática remonta aos antecedentes da Vulgata. Embora não seja dado destaque à mulher nas crónicas que contêm elementos arturianos (textos pseudo-históricos), é aí que são lançados os dados que constituem o eixo do ciclo em prosa: o rapto de Guenièvre por Mordret e, mais tarde, a inserção de Lancelot no ciclo, tema de origem folclórica que tinha inicialmente, segundo J. Weston, Gauvain como protagonista, o qual terá sido substituído por Lancelot a partir do Lai de Lanval. O tema da rainha que passa entre os mundos, o herói criado por uma fada e a transição entre os reinos vão ser os ingredientes fundamentais da evolução heróica presa à mediação feminina. 
A visão da mulher no universo arturiano é completada, nos seus antecedentes, pelas componentes mitológica e folclórica, respectivamente dos ramos do folclore bretão: continental (mitologia francesa), insular (fundo mitológico celta: irlandês, galês, bretão) e o fundo galo-romano. Mas é só com Chrétien de Troyes que a atenção é deslocada para a mulher. Ela passa a fazer parte do percurso do herói e dos temas da sua evolução: o "paraíso feminino", o "paraíso materno", o Outro Mundo da fada, a alternância cíclica e, finalmente, o Graal. É também Chrétien que põe em destaque a imagem física da mulher, equiparando-a, através da sua perfeição, beleza e pureza, à Ordem e abundância.

Nos textos em prosa, começará a dar-se mais destaque à descrição do herói em detrimento da mulher. Na primeira parte da Vulgata as descrições são vagas, mas começa a delinear-se o protagonismo de Niniane, Morgain e Guenièvre, as quais preparam o advento dos grandes heróis, enquanto nas últimas partes da Vulgata a beleza, demonizada e sinónimo de tentação, será impeditiva da evolução do herói, desaparecendo mesmo na Post-Vulgata, parte do ciclo já afastada das raízes míticas e cujo papel do Graal surge totalmente cristianizado. A noção de pecado revela uma imagem perigosa da mulher. É essencialmente esta a que passou para a posteridade. $\mathrm{O}$ insucesso dos heróis passa a estar ligado à mulher (Lancelot pelo pecado, Perceval pela tentação, Boorz pela relação anterior com uma mulher). Mas, em contrapartida, a mulher, ao conduzir ao pecado, leva também à redenção, já que sem pecado não há arrependimento. Cada uma das partes da Vulgata (Joseph, Merlin e Arthur, por um lado, e o Lanceot, a Queste e a Mort Artu, por outro) apresenta uma imagem funcional diferente da mulher, começando na sua condição no ciclo, passando pela questão da condenação, e terminando no arrependimento e redenção do herói.

Porém, antes de lhe ser conferida uma visão moralizante, já o feminino arturiano se radicava na mitologia celta e europeia, encontrando a sua génese na Grande Deusa mítica. As três personagens femininas que atravessam todo o ciclo, a Dama do Lago, Guenièvre, Morgain, estão ligadas às deusas lunares e, por conseguinte, à água, cenário arturiano por excelência e veículo de duplicação dos heróis. Elas são faces da deusa tríplice, pois presidem ao nascimento, evolução e morte do herói. Niniane, a Dama do Lago (epíteto que lhe é dado por Merlin), corresponde ao arquétipo de Diana, deusa lunar, selvagem e casta. Ela favorece a linhagem do rei Ban, faz a preparação do herói (Lancelot) que fará a passagem entre os reinos necessária à alternância cíclica do reino 
de Artur, e substitui-se a Merlin, passando ela mesma a ser a profetisa. É o início do reinado das fadas que preparam os heróis e, por conseguinte, o início do tempo destes. Morgain, tal como Niniane, está ligada ao elemento aquático e é correspondente à deusa Morrigan da mitologia celta, desempenhando papéis muito diferentes nos vários textos, que vão da figura materna, ao favorecimento ou desfavorecimento dos heróis, e ao acolhimento na morte. Niniane e Morgain, correspondendo às faces lúbrica e virgem da deusa lunar, terão sido inicialmente uma mesma deusa. Encontram paralelismo em Lunete e Laudine, personagens desenvolvidas por Chrétien de Troyes em Yvain. A Dama de Avalon é também senhora do elemento aquático, mas nada tem a ver com a Dama do Lago. É companheira de Morgain e mediadora de algumas aventuras determinantes para a maturação heróica. Guenièvre, por seu turno, surge como reminiscência das deusas ctónicas, também lunares, fazendo regenerar a vegetação com o movimento da sua passagem entre os mundos, colocando Lancelot no centro do ciclo arturiano.

Os textos arturianos apresentam igualmente as figuras femininas da superfície, que ligam mundos feéricos, herdando do folclore celta e da mitologia galo-romana as deusas essenciais. As personagens cavalares (Rhiannon, Enide, Isolda) são reminiscências da Epona galo-romana.

Durante a infância, os heróis arturianos encontram o seu primeiro espelho na figura feminina. Relativamente à infância, partimos do esquema heróico de Otto Rank, de 1909. Contudo, o problema do feminino traz novidades quanto à sua aplicação, começando pela própria concepção do herói. A mulher é o primeiro veículo do nascimento do herói, seja ele secreto (proibido, pela desonra da mãe, como Gauvain, ou incestuoso, em que a mãe é irmã do rei Artur, como acontece com Mordret) ou manipulado, sendo a mulher usada por alguém (como no nascimento forçado, em caso de violação, em que temos heróis como Tor, Artur o Pequeno, ou Meraugis; ou no nascimento mágico, por intervenção de Merlin ou uma de encantadeira: no primeiro caso, heróis como Artur e Hector des Marès e, no segundo caso, Helain le Blanc). A mulher pode ser também veículo do nascimento quando concede dons à nascença (tal como as forças solares de Gauvain, que foram concedidas por fadas) ou predestina, directa ou indirectamente, o herói (como Perceval, que é oferecido a Deus pelo pai, contrariando a vontade da mãe, e Tristão, que é um filho longamente esperado por uma mãe que não podia conceber). 
As progenitoras são necessárias à predestinação dos heróis, começando pela concepção. Mas o papel materno estende-se pela criação e educação dos heróis, que podem ser mediadas pela mãe verdadeira ou pela mãe adoptiva. Neste último caso, dá-se o chamado "segundo nascimento" do herói, necessário à sua duplicação e formação da identidade heróica, o qual pode acontecer na floresta ou na água. O duplo nascimento do herói é uma manipulação do tempo. A imersão nas águas (ou o nascimento na floresta) é um "regressus ad uterum". A mesma manipulação acontecerá, mais tarde, na descida ao mundo subterrâneo (protagonizada por Lancelot, para ir buscar a rainha Guenièvre). Há uma reformulação da condição do herói, em que este renasce sob a forma heróica, sob a mediação feminina. Enquanto a floresta pode ser local de nascimento feérico ou não (Floriant, Gauvain, Tristão e Perceval são heróis nascidos na floresta), a água é o elemento mais fascinante da duplicação do nascimento (Lancelot, Gauvain, Meliadus) e o que tem maior destaque.

A infância dos heróis é condicionada à acção feminina. $\mathrm{O}$ herói pode ter vivido sempre com a mãe (Perceval) ou pode não a ter conhecido (Tristão). Mas a maior parte dos heróis tem uma criação adoptiva, que pode ser feérica ou não. Há heróis que são criados por fadas (Lancelot, Boorz, Lionel, Floriant), mas também há os que são efectivamente filhos de fadas (Yvain, Erec). As fadas são, de facto, as mães mais carinhosas, e têm a característica de cuidar dos filhos alheios, educando-os para os devolverem ao mundo sob a forma cavaleiresca. É por isso que a mulher está presente, directa ou indirectamente, na maior parte das investiduras, sendo ela própria a armar o cavaleiro ou enviando armas para o efeito. Por outro lado, vai construir a identidade do herói (cujo passado paterno é desconhecido), sob a forma de discurso, fazendo a separação relativamente ao presente, a qual é necessária para que o herói possa passar à fase de maturação e provação do seu percurso.

É aqui que entram, no percurso heróico, as intermediárias, quer como adjuvantes quer como oponentes, mediando discursivamente (através de anúncios ou profecias) ou activamente (protegendo, auxiliando ou não) o caminho a percorrer. A mediação feminina é um marco na errância do herói, que se compõe da intervenção intermitente da mulher. A donzela é a personagem forte desta fase. Ela aparece a indicar caminhos, a conduzir o herói, a anunciar aventuras, a acompanhar ou a surgir esporadicamente. $\mathrm{O}$ herói conta sempre com a protecção da mulher, que engana os inimigos, dá protecções mágicas e avisos, e faz a mediação das armas, concedendo-as ou tirando-as ao herói. 
Por outro lado, a mulher surge ainda na mediação de encontros amorosos, os quais podem dever-se a uma encantadeira, que poderá intervir no processo de preservação da linhagem, quando há necessidade da concepção de uma criança por um cavaleiro perfeito (é o que acontece com Galaad, filho de Lancelot).

Contudo, a identidade heróica continua a evoluir e, mais uma vez, a mulher intervém na sua maturação. A mulher pode conceder a identidade ao herói, revelando o seu nome. Ou pode ocultá-lo perante os outros, ajudando o herói a ganhar tempo para construir a sua identidade. Essa aura de mistério cria uma imagem sobre a bravura do herói, pela qual damas e donzelas se apaixonam. Sem nunca terem visto o cavaleiro (como, por exemplo, Gauvain, que é o mais desejado), as mulheres amam uma imagem de valentia que se interpõe entre elas e o herói.

O caminho da aventura heróica é percorrido em termos de tempo e espaço. A maior provação à circulação do herói é precisamente o feminino, ao qual o herói tem de resistir. Os espaços são povoados de mulheres tentadoras que põem em perigo a cavalaria, provocando o esquecimento do tempo em que se encontram os heróis. $\mathrm{Na}$ cavalaria errante, o herói pode ficar retido no mundo das fadas. Belas e ricas, podem seduzi-lo e pôr em perigo a sua evolução. Mas há dois tipos de fadas: a fada do tipo "cavalar", que conduz o herói à aventura, oferece-lhe o seu amor e deixa em aberto a possibilidade de ele voltar quando quiser, e a fada aprisionadora, que quer o herói só para ela (é disso que todos os heróis fogem, chegando mesmo a haver paródias sobre o tema). O "paraíso feminino" é uma prisão. A mulher dá o amor em troca da renúncia à liberdade. Então o paraíso torna-se um inferno. Os heróis gostam de ser curados dos seus ferimentos pelas fadas. Mas correm grande risco de ficarem presos a elas. Há, inclusivamente, fadas que raptam cavaleiros das enfermarias convencionais e levam-nos para os seus domínios (como em Claris et Laris).

Apaixonando-se a mulher pela imagem heróica do cavaleiro, se ele renunciar à cavalaria por amor, ela deixará de amá-lo. A solução do problema consiste em criar a cavalaria "à porta de casa”. O herói fica a defender o castelo até chegar outro que o vença. Nesse caso, se outro for melhor do que ele, a mulher apaixona-se pelo vencedor, porque o que ela ama é a imagem de valentia que tem do cavaleiro (como no Didot-Perceval e Yvain). Se o casamento implicar ficar em casa com a mulher, isso é sinónimo de cobardia, já que a imagem do cavaleiro, construída pelos seus feitos e aventuras, é posta em causa. Muitos heróis são avisados desse perigo. 
A evolução pode encontrar obstáculos quando a mulher é tentadora, opondo-se ao prosseguimento do caminho do herói. A mulher pode seduzir sem ser uma fada. Neste caso, as consequências para o herói têm mais a ver com o impedimento da aventura do Graal. Ou a mulher surge demonizada ou o tema do aprisionamento é exagerado (como em Perlesvaus, em que uma donzela mutilava os cavaleiros para que estes não fugissem). O herói encontra oponentes femininas que podem não ser sedutoras. Podem apenas querer dificultar-lhe o percurso. Há também as que denunciam o herói, com o fim de prejudicá-lo (designadamente Bessile, que denuncia o amor de Tristão e Isolda, e Morgain, que denuncia a relação de Lancelot e Guenièvre).

O percurso volta a ser mediado pelo feminino quando o herói depara com um jogo de duplos e espelhos, os quais tem de eliminar, a fim de fixar a sua identidade. O cavaleiro pode disputar a mulher com outro, trocá-la, recusá-la, ou eliminar o adversário. O herói pode ser abandonado pela mulher (é o que acontece com Gauvain, questão que se pode prender com a substituição do amante, representada por Lancelot numa tradição oral anterior), ser testado pela fidelidade ou infidelidade feminina, ou recusar a mulher que ganhou em disputa, como forma de não ficar "preso" e poder continuar o seu percurso.

Numa determinada altura, há como que uma destruição do percurso do herói, correspondente a uma reformulação. Há mulheres que salvam os heróis (como a irmã de Perceval, que salva Galaad, na Demanda do Santo Graal), mas também há as que causam perturbação na consciência do herói (como a donzela que pede a cabeça da irmã de Erec). Outras sofrem a sedução e a desonra. Outras ainda chamam o herói à consciência com a reprovação dos seus actos. É o tempo da reformulação do percurso, mediada pela acção feminina.

Contudo, se o percurso do herói foi marcado pelo Caos, correspondente à regeneração necessária ao processo de maturação, a Ordem é reposta pela mulher: quer a curar ferimentos, quer a substituir o próprio herói num momento do percurso, quer casando com ele simbolicamente para fazer florescer a vegetação, quer ainda mediando, por alternância cíclica, o seu acesso à soberania.

A finalização do processo heróico é marcada também pela mulher. Ou ela surge como recompensa, no casamento (no final de um texto), ou é motivo de arrependimento, em consequência do pecado, levando assim à salvação (contribuindo para a edificação do herói), ou assiste à morte (neste caso, a última face da deusa tríplice apresenta-se, cumprindo o seu papel natural). A Grande Deusa revela a sua faceta lunar de 
recolhimento, recebendo o herói no seu seio simultaneamente protector e aprisionador de tranquilidade. É o que acontece quando Artur é recolhido em Avalon (segundo, nomeadamente, o Didot-Perceval). Mas há situações em que a morte pode ser igualmente uma forma de prisão feminina, à semelhança dos episódios em que o herói fica preso nos encantos do paraíso feminino. É o caso de textos como Perlesvaus, em que os perigos do paraíso feminino são levados ao extremo.

Do nascimento à morte, a maturação heróica não prescinde do elemento feminino. Os heróis arturianos não nascem nem evoluem, não ganham uma imagem identitária nem terminam o seu percurso sem as fadas, as damas, as donzelas mediadoras, bem como as representantes da Grande Deusa (depurada pelo folclore e recriada na tradição romanesca) que não só o acompanham nas narrativas medievais, como determinam a sua condição heróica, como primeiro e último espelho da sua identidade.

\section{COMO CITAR ESTE ARTIGO}

\section{Referência electrónica:}

CHORA, Ana Margarida - A Deusa em Camelot: o papel da mulher na concepção e evolução dos heróis arturianos. Tese de Doutoramento em Literaturas Românicas apresentada à Faculdade de Ciências Sociais e Humanas da Universidade Nova de Lisboa, em Novembro de 2008. Medievalista [Em linha]. №8, (Julho de 2010). [Consultado dd.mm.aaaa]. Disponível em http://www2.fcsh.unl.pt/iem/medievalista/MEDIEVALISTA8lchora8012.html. ISSN 1646-740X.
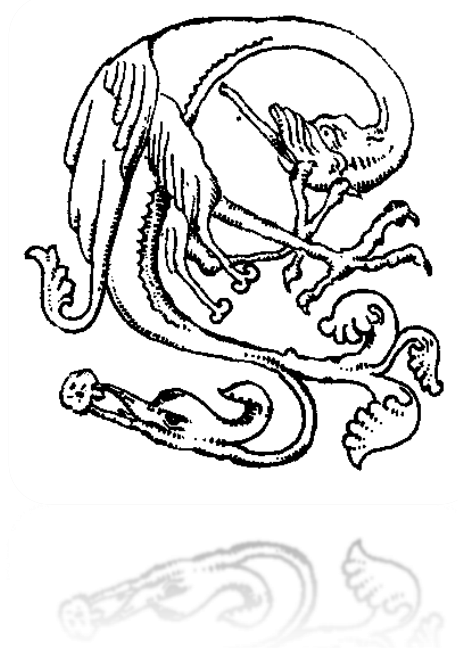